\title{
The EU's Regulation on the Sustainable Management of External Fishing Fleets: International and European Law Perspectives
}

\author{
Solène Guggisberg \\ Netherlands Institute for the Law of the Sea (NILOS), Utrecht University, \\ Utrecht, The Netherlands; Nippon Foundation Nereus Program \\ s.a.guggisberg@uu.nl
}

\begin{abstract}
The European Union's (EU) new Regulation on the sustainable management of external fishing fleets strengthens the framework under which authorisations are granted to EU vessels desiring to fish outside of EU waters. It applies to all such fishing activities, conditions the granting of authorisations on sustainability criteria, and provides a level of institutional control on Member States' actions, as well as some transparency. It also covers poorly monitored practices, such as reflagging and chartering. However, there have been some missed opportunities, in particular with regard to unregulated high seas fishing and the public accessibility of data on beneficial ownership. More generally, the impact on sustainability of the EU's stricter measures will depend, in the highly inter-connected world of fisheries, on whether other States also embrace such good governance principles.
\end{abstract}

\section{Keywords}

fisheries - European Union (EU) - Common Fisheries Policy (CFP) - external fishing fleet - distant-water fishing 


\section{Introduction}

In December 2017, the European Union (EU) adopted a new Regulation on the sustainable management of external fishing fleets (SMEFF Regulation). ${ }^{1}$ It repeals Council Regulation (EC) No 1006/2008 of 29 September 2008 concerning authorisations for fishing activities of Community fishing vessels outside Community waters and the access of third-country vessels to Community waters (Fishing Authorisation Regulation), ${ }^{2}$ a Regulation which has been criticised as lacking consistency, leaving some fishing practices poorly monitored, and creating a deficient framework in terms of transparency. ${ }^{3}$ The SMEFF Regulation, like the Fishing Authorisation Regulation before it, forms one of the three pillars of the Common Fisheries Policy (CFP) of the EU, together with the Regulation on illegal, unreported and unregulated fishing (EU IUU Regulation) ${ }^{4}$ and the Control Regulation, ${ }^{5}$ and is established under

1 The author thanks Erik J. Molenaar for his insightful comments on an earlier version of this article and the anonymous reviewer for his or her useful remarks. She acknowledges support from the Nippon Foundation Nereus Program, a research collaboration between Utrecht University and 17 partner institutions. Regulation (EU) 2017/2403 of the European Parliament and of the Council of 12 December 2017 on the sustainable management of external fishing fleets (SMEFF Regulation), OJ L 347, 28 December 2017, 81-104. It was adopted following an ordinary legislative procedure, also known as co-decision, where the European Parliament and Council have to reach an agreement (Consolidated Version of the Treaty on the Functioning of the European Union (TFEU), OJ C 115, 9 May 2008, 47-200, Article 294). This means that, on the basis of a proposal by the Commission and with the help of the Commission, the two institutions had to find common ground during the trilogue phase of the negotiations.

2 Council Regulation (EC) No 1006/2008 of 29 September 2008 concerning authorisations for fishing activities of Community fishing vessels outside Community waters and the access of third country vessels to Community waters (Fishing Authorisation Regulation), OJ L 286, 29 October 2008, 33-44.

3 I Popescu, 'New rules for managing the EU external fishing fleet' (Briefing EU Legislation in Progress, July 2017) available at http://www.europarl.europa.eu/RegData/etudes/ BRIE/2017/608651/EPRS_BRI(2017)608651_EN.pdf; accessed 21 August 2018, at pp. 2-3; EJF, Oceana, Pew, and wwF, 'Ensuring better control of the EU's external fishing fleet' available at http://www.whofishesfar.org/files/Case_Studies/FAR_Narrative.ENG.FINAL.30.6.pdf; accessed 21 August 2018, at p. 3 .

4 Council Regulation (EC) No 1005/2008 of 29 September 2008 establishing a Community system to prevent, deter and eliminate illegal, unreported and unregulated fishing (EU IUU Regulation), OJ L 286, 29 October 2008, 1-32.

5 Council Regulation (EC) No. 1224/2009 of 20 November 2009 establishing a Community control system for ensuring compliance with the rules of the common fisheries policy (Control Regulation), OJ L 343, 22 December 2009, 1-50. 
the framework of the CFP Basic Regulation. ${ }^{6}$ The SMEFF Regulation focuses on the external dimension of the CFP, that is the activities of EU Member States' vessels outside of EU waters and of third countries' vessels within EU waters. Consisting of 48 Articles and an Annex listing the data to be sent to the European Commission (Commission), the SMEFF Regulation sets out the conditions for EU Member States, as flag States, to issue fishing authorisations to their vessels. It also lists the conditions under which the Commission may issue fishing authorisations to the vessels of third countries wanting to fish in EU waters. Finally, it establishes certain institutional processes to control Member States' decision-making.

Historically, until the rapid extension of coastal States' jurisdictional claims in the second half of the 2oth century, fishing by vessels from distant-water fishing States, that is by vessels not exclusively active in the waters of their flag State, principally took place on the high seas. With the widespread establishment of exclusive economic zones (EEZs), the area of the high seas was vastly reduced, as was access to many commercially exploited fish species, which are found mainly within 200 nautical miles of the coast. ${ }^{7}$ Consequently, a large portion of distant-water fishing now takes place in the EEzs of third States, although an important increase in fishing beyond 200 nautical miles has also been noticed. ${ }^{8}$

The fishing fleets of EU Member States are active in areas under the jurisdiction of third States and on the high seas, both in areas under the management of regional fisheries management organisations (RFMOs) and in unregulated zones or towards unregulated species, which amounts to unregulated high seas fishing (see infra, section on Unregulated High Seas Fishing). Fishing within the EEzs of third States is mainly undertaken within the framework of sustainable fisheries partnership agreements (SFPAs), which are bilateral agreements between a coastal State and the EU. Other kinds of bilateral agreements exist with coastal States with which the EU shares stocks of common interest. ${ }^{9}$ These agreements are referred to in the SMEFF Regulation as "agreements on exchange or joint management" and fishing authorisations are issued in the

6 Regulation (EU) No. 1380/2013 of the European Parliament and of the Council of 11 December 2013 on the Common Fisheries Policy (CFP Basic Regulation), OJ L 354, 28 December 2013, 22-61.

7 DR Rothwell and T Stephens, The International Law of the Sea (2nd ed., Hart Publishing, Oxford, 2016), at p. 320.

8 W Swartz, E Sala, S Tracey, R Watson, and D Pauly, 'The Spatial Expansion and Ecological Footprint of Fisheries (1950 to Present)' (2010) 5(12) PLoS ONE 1-6, at p. 2.

9 On stocks of common interest, see CFP Basic Regulation (n 6), Article 33. 
same manner as under SFPAs..$^{10}$ Consequently, for the present analysis, this category will be merged with SFPAs. Under SFPAs, the coastal State receives payment and some support specifically directed at improving fisheries governance, and the EU is granted access rights to certain fishing grounds. SFPAS are long-lasting framework treaties, which are supplemented by shorter-term protocols. ${ }^{11}$ In the absence of a protocol in force, an SFPA is said to be dormant, and fishing by EU vessels cannot take place. When an SFPA exists, whether it is active or dormant, EU vessels cannot enter into private agreements with the coastal State to fish in its EEz. This fourth kind of external fishing may occur where no SFPA has been established and is called fishing under direct authorisations. It relies on direct links between the operators and the coastal State, without the involvement of the EU.

As provided for in the 1982 United Nations Convention on the Law of the Sea (LOSC), the flag State is under the obligation to "effectively exercise its jurisdiction and control in administrative, technical and social matters over ships flying its flag". ${ }^{12}$ In the fisheries sector, the content of the flag State obligation is further elaborated in several instruments, in particular the 1993 Food and Agriculture Organization (FAO) Agreement to Promote Compliance with International Conservation and Management Measures by Fishing Vessels on the High Seas (Compliance Agreement) ${ }^{13}$ and the 1995 United Nations Fish Stocks Agreement (UNFSA). ${ }^{14}$ Accordingly, flag States are responsible for controlling their vessels and ensuring that they respect the applicable conservation and management measures which may be adopted by a coastal State and/ or an RFMO, depending on where the fishing takes place and what species are targeted. ${ }^{15}$

\footnotetext{
$10 \quad$ SMefF Regulation (n 1$)$, Article 14.

11 For an overview of existing fisheries agreements involving the EU, see European Commission, 'Bilateral agreements with countries outside the EU' available at https:// ec.europa.eu/fisheries/cfp/international/agreements_en; accessed 21 August 2018.

12 United Nations Convention on the Law of the Sea (LOSC) (Montego Bay, 10 December 1982, in force 16 November 1994) 1833 UNTS 396, Article 94(1).

13 Agreement to Promote Compliance with International Conservation and Management Measures by Fishing Vessels on the High Seas (Compliance Agreement) (Rome, 24 November 1993, in force 24 April 2003) 2221 UNTS 120.

14 Agreement for the Implementation of the Provisions of the United Nations Convention on the Law of the Sea of 10 December 1982 relating to the Conservation and Management of Straddling Fish Stocks and Highly Migratory Fish Stocks (UN FSA) (New York, 4 August 1995, in force 11 December 2001) 2167 UNTS 88.

15 Such obligations are also referred to in the Sustainable Fisheries Resolutions adopted by the United Nations General Assembly (UNGA) (see for example UNGA, 'Sustainable fisheries, including through the 1995 Agreement for the Implementation of the Provisions of the United Nations Convention on the Law of the Sea of 10 December 1982 relating to
} 
The situation of the EU and its Member States vis-à-vis flag State duties is quite particular, with a division of competence - and hence responsibility defined in EU founding instruments and clarified at the international level through two declarations made by the EU when it signed the LOSC and the UNFSA. ${ }^{16}$ On the one hand, EU Member States retain their role as flag States, accepting vessels on their registers, granting authorisations to fish, and, if necessary, imposing sanctions. On the other hand, the EU enjoys exclusive competence with regard to the conservation of marine biological resources under the CFP. ${ }^{17}$ In particular, the EU is responsible for entering into SFPAs and, as a general rule subject to some exceptions, for acting within R FMOs. ${ }^{18}$ This means that, under international law and for such fishing types, the EU is ultimately the actor subject to the "due diligence obligation' to take all necessary measures to ensure compliance and to prevent IUU fishing by fishing vessels flying its flag"19 (see infra, section on Control by the Commission).

This article analyses the extent to which the SMEFF Regulation ensures that the EU respects its global international obligations - regional frameworks are excluded, although the EU is bound by the measures adopted within the RFMOs of which it is a member - taking into account, when relevant, soft-law instruments as evidence of best practice. ${ }^{20}$ This article also examines whether

the Conservation and Management of Straddling Fish Stocks and Highly Migratory Fish Stocks, and related instruments' (A/Res/72/72, 5 December 2017), Preamble, para. 11).

16 European Community's Declaration made upon signature of the LOSC, in relation to Article 2 of Annex IX; European Community's Declaration made upon signature of the UNFSA, in relation to its Article 47.

17 TFEU (n 1), Article 3(d).

18 See CFP Basic Regulation (n 6), Articles 29-32. There are ratione materiae exceptions, such as that decisions regarding broader environmental protection issues are not covered by the exclusive competence of the EU, as well as ratione personae exceptions, such as that certain territories of EU Member States are not subject to the TFEU - these territories are represented by the Member States rather than the EU in RFMOs (TFEU (n 1), Article 355 and Annex II; R Churchill and D Owen, The EC Common Fisheries Policy (Oxford University Press, Oxford, 2010), at pp. 359-360).

19 International Tribunal for the Law of the Sea (ITLOS), Request for an Advisory Opinion Submitted by the Sub-Regional Fisheries Commission (SRFC), Advisory Opinion, 2 April 2015, ITLOS Reports 2015, para. 129, read together with paras. 172-173.

20 FAO Guidelines and Plans of Actions, for example, are adopted following a comprehensive procedure of negotiation where States are fully involved. It can be said that the resulting documents reflect an agreement of States, maybe not of what they must do, but at least of what they should do. The FAO International Plan of Action to prevent, deter and eliminate illegal, unreported and unregulated fishing (IPOA-IUU) (Rome, 2001) is considered a toolbox in the fight against IUU fishing and hence is often used as a source of inspiration for policy decisions (see W Edeson, 'The International Plan of Action on Illegal, Unreported and Unregulated Fishing: The Legal Context of a Non-Legally Binding 
the SMEFF Regulation is consistent with EU law, in particular with the CFP Basic Regulation. By comparing the SMEFF Regulation to the instrument it replaces, this article highlights areas where improvements have been made and identifies some missed opportunities. The focus is on EU distant-water fishing; questions related to access by third States' vessels to EU waters are not considered. The analysis begins with a presentation of the SMEFF Regulation's scope of application, continues with an assessment of the substantive quality of the requirements to be followed for an authorisation to be granted, and finishes with an examination of the institutional structure put in place to avoid and, if necessary, address violations.

\section{Wider Scope of Application}

The SMEFF Regulation covers all possible types of external fishing, whether it takes place within the framework of an SFPA or RFMO, under direct authorisations, or in unregulated high seas areas. As examined below, this is a major change in scope and consistency in relation to the two types of fishing which were not fully regulated in the Fishing Authorisation Regulation. Moreover, the framework of the SMEFF Regulation extends to EU vessels involved in chartering operations, activities which were not addressed in the earlier instrument.

\section{External Fishing Wherever It Takes Place}

Under international law, the flag State must control its vessels, regardless of whether they are active on the high seas or in the EEz of a third State. ${ }^{21}$ In addition to this general international law obligation, the EU is bound by a precise rule found in the Compliance Agreement. In keeping with these obligations, the relevant authorities must issue an authorisation before any vessel is allowed to fish on the high seas. ${ }^{22}$ Soft-law instruments also restate the importance of such control by the flag State, in terms that are not always restricted

Instrument' (2001) 16(4) The International Journal of Marine and Coastal Law 603-623, at p. 623). Of relevance is also a soft-law instrument adopted at the FAO Committee on Fisheries in 2014, which promotes flag State performance assessments and lists, as criteria, the most widely accepted flag State obligations (Voluntary Guidelines for Flag State Performance (Rome, 2014)).

21 LOSC (n 12), Article 94(1); ITLOS, Request for an Advisory Opinion Submitted by the SRFC (n 19), paras. 115-116.

22 Compliance Agreement (n 13), Article III(2); see also UnFSA (n 14), Article 18(3)(b)(ii). 
to the high seas. ${ }^{23}$ Fishing within the framework of an SFPA or RFMO was covered in the Fishing Authorisation Regulation and remains so in the SMEFF Regulation. What has changed is that the latter Regulation now also applies in an equal measure to fishing under direct authorisations and unregulated high seas fishing, thus covering external fishing wherever it takes place.

Fishing under direct authorisations was mostly ignored by the Fishing Authorisation Regulation. Member States were to "endeavour to obtain information" on such arrangements and inform the Commission. ${ }^{24}$ Under that instrument, only a list of the vessels concerned was to be transmitted. In such circumstances, there was a clear gap in the information available to the Commission and no standardised conditions for flag States to issue authorisations. Such fishing is now regulated under the SMEFF Regulation, not only with common criteria to be used by all flag States when deciding whether to issue an authorisation, ${ }^{25}$ but also with a strong obligation to share information with the Commission before an authorisation is issued. ${ }^{26}$ This ensures that the Commission can react before fishing takes place if an operation is planned in the waters of a third country with which the EU has an SFPA. Such fishing is forbidden under the exclusivity clause of the CFP Basic Regulation, but this rule was hardly enforceable in the absence of relevant information. Although the flag States should be the ones to deny fishing authorisations in those circumstances, it appears not always to have been the case. ${ }^{27}$

For unregulated high seas fishing, the Fishing Authorisation Regulation also established an ab minimo framework. All that was required from Member States was to issue an authorisation in accordance with national provisions and

23 IPOA-IUU (n 20), para. 45. As to the Voluntary Guidelines for Flag State Performance, while they refer to the importance of having a regime in place for authorising fishing, their scope of application is mainly focused on areas beyond national jurisdiction (Voluntary Guidelines for Flag State Performance (n 20), paras. 3, 29-30).

25 SMEFF Regulation (n 1), Articles 5, 17.

26 Ibid., Article 18(1).

27 See for example the case of Italian vessels in West Africa as presented in CAPE / CFFA, 'EU Common Fisheries Policy External Dimension: Improving sustainability through an ambitious revision of the Fishing Authorisation Regulation' (September 2016) available at https://static1.squarespace.com/static/517fe876e4bo3c6b86a4b81b/t/57e3bc4d29687f gf87206a62/1474542693881/Improving+sustainability+through+an+ambitious+revision+ of+the+Fishing+Authorisation+Regulation.pdf; accessed 21 August 2018, at p. 4; see also V Vulperhorst, L Malarky, MJ Cornax, and B Lowell, 'Fishing the Boundaries of Law How the Exclusivity Clause in EU Fisheries Agreements Was Undermined' (Oceana, September 2017) available at https://oceana.org/publications/reports/fishing-boundaries-law-how-exclusivity-clause-eu-fisheries-agreements-was; accessed 21 August 2018, at pp. 6-8. 
to give the Commission, ten days in advance of the fishing operation's starting date, information about the vessels, species, fishing gear, period, and area of activity. ${ }^{28}$ In comparison, the SMEFF Regulation now regulates the activities of Member States' vessels on the high seas, setting criteria that are common to the flag States issuing such authorisations ${ }^{29}$ and imposing an obligation to provide data to the Commission. ${ }^{30}$

Strictly speaking, the EU was already in a position to respect its international obligations before the SMEFF Regulation. The Fishing Authorisation Regulation regulated the issuance of authorisations for fishing under SFPAS and RFMOs. For the other types of fishing, Member States, not the EU, are ultimately responsible, as flag States, for controlling their vessels. The SMEFF Regulation nevertheless strengthens the framework by ensuring that fishing under direct authorisations and unregulated high seas fishing are also covered by the general criteria of eligibility and are overseen by the Commission. Although not strictly necessary for these two types of fishing, the extension of the legislation's scope is a welcome increase in consistency and facilitates some centralised control.

\section{Chartering}

Chartering is defined as "an arrangement by which a fishing vessel flying the flag of a Member State is contracted for a defined period by an operator in either another Member State or a third country without a change of flag". ${ }^{31}$ Chartering practices can blur the responsibilities of various kinds of States, leading to a situation where no State takes responsibility for reporting catches or controlling vessels. Moreover, many chartering activities go unreported, creating gaps in the information available and limiting the control of a flag State over its fleet. ${ }^{32}$ Consequently, it is likely that these arrangements are at times used to circumvent regulations.

International treaties are silent on the question of chartering. It is mentioned in a leading soft-law instrument, the 2001 FAO International Plan of Action to prevent, deter and eliminate illegal, unreported and unregulated (IUU) fishing (IPOA-IUU), with the comment that "[a]ll States involved ... should, within the limits of their respective jurisdictions, take measures to ensure that chartered

\footnotetext{
28 Fishing Authorisation Regulation (n 2), Article 11(1).

29 SMefF Regulation (n 1), Articles 5, 24.

$30 \quad$ Ibid., Article 25(1).

31 Ibid., Article 3(2)(f).

32 Who Fishes Far, 'Transparency, Accountability and Sustainability' available at http:// www.whofishesfar.org/how-to-use-this-database; accessed 21 August 2018.
} 
vessels do not engage in IUU fishing". ${ }^{33}$ Similarly, the FAo Voluntary Guidelines for Flag State Performance, a 2014 soft-law instrument which includes a list of the most widely accepted international obligations of flag States, mentions chartering; however, this is in relation to the obligations of coastal States in their EEZs rather than to the duties of flag States. ${ }^{34}$

In EU fisheries law, chartering is addressed for the first time in the SMEFF Regulation. It was indeed left unregulated in both the CFP Basic Regulation and the Fishing Authorisation Regulation. Articles 26 and 27 of the new instrument provide for limitations on the use of chartering by Member States' fishing vessels. The practice is allowed for fishing under direct authorisations, within the framework of RFMOs, and for unregulated high seas fishing, but not in the waters of a coastal State with which an SFPA exists. ${ }^{35}$ This prohibition is due to the exclusivity clause applicable under SFPAs. Indeed, vessels flagged in an EU Member State cannot be active in the EEZ of a third State outside of the framework of an existing SFPA, even if it is to fish another State's quota. ${ }^{36}$

Article 27 refers back to the procedure for issuing fishing authorisations for each of the three allowed types of fishing. Hence, without being the object of a separate authorisation procedure, chartering is now subjected to the same level of control as fishing for quotas held by Member States. In addition, the flag State (i.e., the Member State) must verify that the chartering State has confirmed the legality of the arrangement under its domestic law and that the required information about time period, fishing opportunities, and area is included in the fishing authorisation. ${ }^{37}$ The Annex of the SM E FF Regulation clarifies that data about chartering must be provided to the Commission. For vessels already holding a fishing licence and intended to be chartered, the Member State is under the obligation to inform the Commission without delay. ${ }^{38}$ The SMEFF Regulation also explicitly states that the fishing opportunities

33 IPOA-IUU (n 20), para. 37.

34 Voluntary Guidelines for Flag State Performance (n 20), para. 5 .

35 SmefF Regulation (n 1), Articles 26(1), 27.

36 European Court of Justice, Criminal proceedings against Ahlström and Others, Judgment of the Court (Third Chamber), 9 October 2014, Case C-565/13, ECLI:EU:C:2014:2273. This case concerns two Swedish vessels chartered to a Moroccan company and fishing in Morocco's EEz on the basis of a license issued by the Moroccan authorities without the intervention of the competent EU authorities. The Court found that chartered vessels are subject to the same rules as all other Community vessels under the relevant SFPA; they consequently are not allowed to carry out fishing activities in EEZs of third States with which an SFPA exists without going through the competent EU authorities. See also I Popescu, 'New rules for managing the EU external fishing fleet' (n 3), at p. 7.

37 SmefF Regulation (n 1), Article 27.

38 Ibid., Article 26(6). 
of the chartering State must be used during a chartering operation ${ }^{39}$ and that the international obligations of the flag State, here the Member State, are not diminished because its vessel is operating under a charter. ${ }^{40}$

Even if a comprehensive framework for chartering operations is not created - for example the chartering of non-EU vessels to fish quotas held by EU Member States is not addressed - the inclusion of these provisions in the SMEFF Regulation provides the beginning of a regulatory structure for a practice which has existed in the margins of the law for too long. It also ensures clarity as to States' responsibilities and a certain level of control by the Commission over an elusive part of the fleet.

\section{Stricter Criteria}

The SMEFF Regulation sets out the conditions to be fulfilled for a fishing authorisation to be issued by a flag State. As examined below, some of these criteria are general and apply equally to all types of fishing, whereas others, related to the sustainability of the planned fishing operation, are different for each type of fishing. The Fishing Authorisation Regulation already provided some general criteria, although they only applied to the two types of fishing substantially covered by that Regulation (see supra, section on External Fishing Wherever It Takes Place). A number of general eligibility criteria and all the specific criteria are new to the SMEFF Regulation; these requirements are examined in detail here.

\section{General Eligibility Criteria}

Certain general requirements must be fulfilled for fishing authorisations to be granted by flag States. For example, in both the SMEFF Regulation and the Fishing Authorisation Regulation, such criteria include that the vessel is not on an IUU list and that relevant fishing opportunities are available to the flag State. ${ }^{41}$ Other criteria are new in the SMEFF Regulation. In particular, the flag State can now only issue a fishing authorisation for vessels that have an International Maritime Organization (IMO) number, as required by EU law. Also, if a vessel has been reflagged in the previous five years, it must satisfy a

39 Ibid., Article 26(4).

$40 \quad$ Ibid., Article 26(5).

41 For the full list of general eligibility criteria, see Fishing Authorisation Regulation (n 2), Article 5; and SMefF Regulation (n 1), Article 5. 
set of criteria meant to ensure that, in that period of time, it has not engaged in IUU fishing or otherwise participated in unsustainable fishing practices.

\section{IMo Number}

The SMEFF Regulation makes it a condition of eligibility for a fishing authorisation that a vessel has an IMO number, as required by EU law. ${ }^{42}$ The IMO number is a unique vessel identifier, a fixed number that follows a vessel from construction to disposal, wherever the vessel is active and whatever flag it is flying. It is a key mechanism to ensure that vessels do not evade scrutiny, and it consequently serves to combat IUU fishing. The IMO number is considered the best unique vessel identifier available. ${ }^{43}$ Until 2013, vessels solely engaged in fishing were excluded from the Iмо scheme. Now, they too are able to obtain IMO numbers. ${ }^{44}$ In 2014, the FAO embraced the IMO number as part of its Global Fishing Vessels Record (FAO Global Record), ${ }^{45}$ a global but voluntary initiative intended to provide a centralised and reliable tool to identify fishing vessels. Although vessel owners are encouraged to get an IMO number and flag States are encouraged to transmit it to the FAO for inclusion in its Global Record, there is currently no global international obligation for flag States of fishing vessels in relation to IMO numbers.

Going beyond its international obligations, the EU has since 2016 required that some of its fishing vessels - along with the vessels flying the flags of nonEU Member States that are fishing in EU waters - have an IMO number. More

42 SMEFF Regulation (n 1), Article 5(1)(c).

43 Mrag Asia Pacific PTy Ltd (on behalf of FAO), 'Investigation of Unique Vessel Identifier (UVI) and Phasing Options' (Brisbane, 26 March 2010) available at http://www.fao.org/ fishery/docs/DOCUMENT/global_record/2010/inf5e.pdf; accessed 21 August 2018, abstract. See also EJF, Oceana, Pew, and WWF, 'The need for mandatory IMO numbers for vessels catching seafood for the EU market' (May 2017) available at http://www.iuuwatch. eu/wp-content/uploads/2017/05/Imo-Numbers-FINAL-1-High-Singles.pdf; accessed 21 August 2018, at p. 1 .

44 The Iмо scheme was first expanded in 2013 to fishing vessels of 100 Gross Tonnage and above (Imo General Assembly, 'Iмо Ship Identification Number Scheme' (Resolution A.1078(28), December 2013)). The scheme coverage was further expanded in 2016 to fishing vessels of less than 100 Gross Tonnage (Iмо General Assembly, 'Iмо Ship Identification Number Scheme' (Resolution A.1117(30), December 2017)). Prior to 2013, some large fishing vessels had obtained unique identification numbers under the IMO scheme, but without the Imo prefix (Mrag Asia Pacific PTy Ltd (on behalf of FAO), 'Investigation of Unique Vessel Identifier (UVI) and Phasing Options' (n 43), at p. 6).

45 FAO, 'Report of the Thirty-first Session of the Committee on Fisheries (Rome, 9-13 June 2014)' (Rome, FAo Fisheries and Aquaculture Report No. 1101, 2015), para. 40(c). See also FAO, 'The Global Record of Fishing Vessels, Refrigerated Transport Vessels and Supply Vessels (Global Record)' (Rome, COFI/2014/Inf.12/Rev.1, 9-13 June 2014), para. 5. 
precisely, according to an amendment to the implementing Regulation of the Control Regulation, the obligation applies to EU vessels (or vessels controlled by EU operators under a chartering agreement) of 100 tons of Gross Tonnage or more, or of 24 meters in length or more, operating exclusively in EU waters; to EU vessels (or vessels controlled by EU operators under a chartering agreement) of 15 meters in length or more operating outside of EU waters; and to all third-country vessels operating in EU waters. ${ }^{46}$

The obligation set out in the SMEFF Regulation thus already existed in EU law; the SMEFF Regulation recalls it but does not expand it. The Commission's original proposal would have made the requirement applicable to the entire external fleet, but it was unsuccessful. ${ }^{47}$ Consequently, for the time being, vessels under 15 meters are excluded. However, as the SMEFF Regulation refers to "Iмо ship identification number scheme insofar as is required under Union [EU] law", any future change in the Control Regulation will be automatically applicable.

\section{Reflagging}

An additional condition relates to reflagging, ${ }^{48}$ the process of changing the country of registration of a vessel. Although this may be done in furtherance of a legitimate commercial decision, reflagging has also been used to avoid fishing regulations and to take advantage of flag States with loose control over their fleets. ${ }^{49}$ The Compliance Agreement was adopted in 1993 with a view to tackling these issues. Article III(5) provides that

[n]o Party shall authorize any fishing vessel previously registered in the territory of another Party [or, under certain conditions, non-Party] that has undermined the effectiveness of international conservation and

46 Commission Implementing Regulation (EU) 2015/1962 of 28 October 2015 amending Implementing Regulation (EU) No 404/2011 laying down detailed rules for the implementation of Council Regulation (EC) No 1224/2009 establishing a Community control system for ensuring compliance with the rules of the common fisheries policy, OJ L 287, 37 October 2015, 6-51, Article 1(4).

47 European Commission, 'Proposal for a Regulation of the European Parliament and of the Council on the sustainable management of external fishing fleets, repealing Council Regulation (EC) No 1006/2008' (Commission's proposal) (2015/0289 (COD), 10 December 2015), Article 5(1)(c).

48 SMefF Regulation (n 1), Article 6.

49 United Nations Conference on Environment and Development, 'Agenda 21' (Rio de Janeiro, 3-14 June 1992) available at https://sustainabledevelopment.un.org/content/ documents/Agenda21.pdf; accessed 7 November 2018, para. 17.45; Compliance Agreement (n 13), Preamble; IPOA-IUU (n 20), paras. 38-39. 
management measures to be used for fishing on the high seas unless it is satisfied that (i) any period of suspension by another Party of an authorization for such fishing vessel to be used for fishing on the high seas has expired; and (ii) no authorization for such fishing vessel to be used for fishing on the high seas has been withdrawn by another Party within the last three years..$^{50}$

The IPOA-IUU likewise declares, with no restriction to fishing on the high seas, that "States should take all practicable steps, including denial to a vessel of an authorization to fish and the entitlement to fly that State's flag, to prevent 'flag hopping"..51

According to the SMEFF Regulation, a vessel which has been reflagged understood here as a vessel that left the EU fishing fleet register, reflagged in a third country, and then returned to the EU fishing fleet register - in the last five years must prove that this was not abusive or intended to circumvent EU rules. In particular, vessels having fished in the waters of third States identified as non-cooperating in the fight against IUU fishing will be barred from receiving an EU external fishing authorisation after they re-register in an EU Member State. The burden of proof is put on the operator to provide information on its vessel's activities during the period in which it was not on a Member State's register, including a complete flag history. ${ }^{52}$

The SMEFF Regulation ensures that the obligation found in the Compliance Agreement in relation to fishing on the high seas will be respected for the vessels that have reflagged in and out of the EU fishing register. For those vessels, the information to be provided by the operator should be sufficient to verify that the conditions of Article III (5) are fulfilled. However, Article 6 of the SMEFF does not apply to vessels which were not registered in the EU in the previous five years (i.e., vessels being flagged in the EU for the first time in that period); this could be considered a lacuna. The SMEFF Regulation does not regulate all aspects of reflagging, such as the conditions under which a Member State should accept a vessel on its register. Nevertheless, in the absence of a comprehensive framework on reflagging in the CFP Basic Regulation, the inclusion of a provision in the SMEFF Regulation at least provides safeguards to prevent vessels that have left a Member State's flag to circumvent EU rules on

50 Compliance Agreement (n 13), Article III(5)(a)-(b).

51 IPOA-IUU (n 20), para. 39. The Voluntary Guidelines for Flag State Performance make reference to flag hopping in relation to the registration of vessels, not to fishing authorisations (Voluntary Guidelines for Flag State Performance (n 20), paras. 16, 23). 
sustainability and IUU fishing from being able to come back to the EU register as if nothing had happened. By so doing, the SMEFF Regulation increases the cost of reflagging for abusive purposes.

\section{Specific Sustainability Criteria}

In addition to the general eligibility criteria relevant to all forms of external fishing, certain specific criteria have been developed in relation to the sustainability of fishing operations. Such criteria are different for each type of external fishing.

\section{Fishing Under Direct Authorisations}

Under the SMEFF Regulation, an operator seeking to fish under direct authorisations in the waters of a third country must provide "a scientific evaluation demonstrating the sustainability of the planned fishing operations, including consistency with the provisions of Article 62 of UNCLOS [LOSC], as applicable". ${ }^{33}$ This evaluation

shall be provided by an RFMO or by a regional fisheries body with scientific competence or shall be provided by, or in cooperation with, the third country. The scientific evaluation emanating from the third country shall be reviewed by a scientific institute or body of a Member State or of the Union. ${ }^{54}$

International law provides that the flag State must ensure that its vessels respect the laws and regulations adopted by the coastal State when fishing within the EEZ of another State. ${ }^{55}$ Ensuring that the quotas sold to third States do not lead to overexploitation of the marine living resources is the coastal State's obligation. ${ }^{56}$ Indeed, international law makes it clear that management obligations fall on the coastal States; they determine the total allowable catches in their $\mathrm{EEZs}^{57}$ and, if there is a surplus, grant access to the relevant stocks to other States. ${ }^{58}$ Coastal States are under the obligation to "ensure through proper conservation and management measures that the maintenance of the living resources in the exclusive economic zone is not endangered by

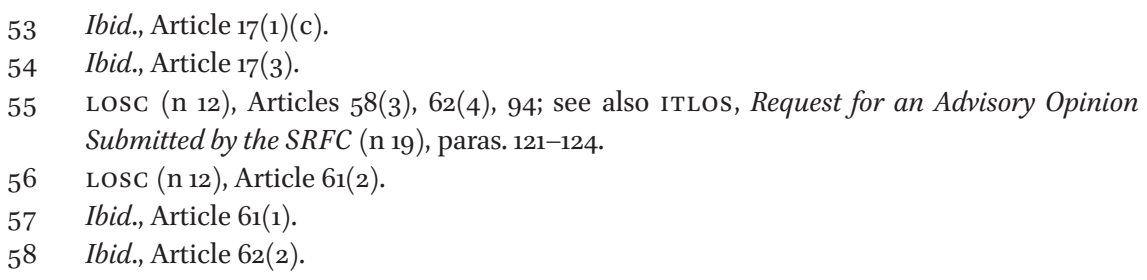


over-exploitation". ${ }^{99}$ However, the recent Voluntary Guidelines for Flag State Performance envisage a dual flag State-coastal State duty, expressed in exhortative ("should") terms:

The flag State should only allow vessels flying its flag to acquire or utilize authorizations outside of [State-to-State access] agreements ... for activities in the maritime areas under the jurisdiction of a coastal State when both States are satisfied that such activities will not undermine the sustainability of living marine resources of that coastal State, taking into account the best scientific evidence available and the precautionary approach. ${ }^{60}$

As a matter of EU law, the CFP Basic Regulation provides that the EU shall apply the same principles and objectives to the internal and external dimensions of its fleet. ${ }^{61}$ Accordingly, it must ensure that fishing is environmentally sustainable in the long-term, apply the precautionary principle, and implement an ecosystem-based approach to fisheries management. ${ }^{62}$

The conditions provided for by the SMEFF Regulation go beyond the requirements of hard international law. International law does not require a flag State to verify the existence of a surplus in the waters of a coastal State or to demonstrate the sustainability of the planned fishing operation. However, it does not forbid a flag State from imposing its own conditions before allowing fishing to occur. The framework provided for by the SMEFF Regulation resembles, albeit in the form of a unilateral obligation, the requirement found in the Voluntary Guidelines for Flag State Performance that both coastal and flag States agree on the sustainability of the planned operation. It also ensures that fishing under direct authorisations can be undertaken in accordance with the sustainability requirements of the CFP Basic Regulation. The SMEFF Regulation, however, remains silent on whether (and if so how) the scientific evaluation should account for the potential impact of fishing by non-EU vessels (from the coastal State or from other flag States to which licenses have also been sold) on relevant stocks. Such information is necessary to guarantee that fishing operations are sustainable in the long-term, but is not often readily available.

Ibid., Article 61(2); see also ITLOS, Request for an Advisory Opinion Submitted by the SRFC (n 19), paras. 189-191.

6o Voluntary Guidelines for Flag State Performance (n 20), para. 41.

61 CFP Basic Regulation (n 6), Articles 3(j), 28(1).

62 Ibid., Article 2(1)-(3). 


\section{Unregulated High Seas Fishing}

The SMefF Regulation establishes the conditions for fishing in areas of the high seas or for species that are not under the management of an RFM ${ }^{63}$ One circumstance where such fishing can be authorised is as part of a research programme. The other refers to fishing operations of a commercial nature. ${ }^{64}$ The requirement for this second scenario is that "the planned fishing operations are in accordance with a scientific evaluation, demonstrating the sustainability of the planned fishing operations, provided or validated by a scientific institute of the flag Member State".65 The addition of such a condition for unregulated high seas fishing is an improvement over the Fishing Authorisation Regulation's cursory obligation to inform the Commission, and it was added at the request of the European Parliament. ${ }^{66}$

Unregulated fishing is part of the IUU trio of activities against which the international community has regularly pledged to fight, most recently in the Sustainable Development Goals. ${ }^{67}$ The aspect of unregulated fishing which may be of relevance to the present discussion is defined in international and European law as fishing "in areas or for fish stocks in relation to which there are no applicable conservation or management measures and where such fishing activities are conducted in a manner inconsistent with State responsibilities for the conservation of living marine resources under international law". 68 It has been recognised in the IPOA-IUU that "certain unregulated fishing may take place in a manner which is not in violation of applicable international law".69

Under applicable international law, States whose vessels are fishing on the high seas must not only control their vessels, but also cooperate in the conservation of the marine living resources. ${ }^{70}$ According to the UNFSA, to which the $\mathrm{EU}$ is a contracting party, cooperation must take the form of participation in

\footnotetext{
63 SmefF Regulation (n 1), Article 24.

64 Ibid., Article 24(b).

65 Ibid.

66 European Parliament, "***I Position of the European Parliament adopted at first reading on 2 February 2017 with a view to the adoption of Regulation (EU) 2017/ ... of the European Parliament and of the Council on the sustainable management of external fishing fleets, repealing Council Regulation (EC) No 1006/2008' (Position of the European Parliament) (EP-PE_TC1-COD(2015)0289, 2 February 2017), Article 26(b).

67 UNGA, 'Transforming our world: the 2030 Agenda for Sustainable Development' (A/Res/ 70/1, 25 September 2015), Goal 14, para. 4.

68 IPOA-IUU (n 20), para. 3.3.2; EU IUU Regulation (n 4), Article 2(4)(b).

69 IPOA-IUU (n 20), para. 3.4.

$70 \quad \operatorname{LosC}(\mathrm{n} 12)$, Article 118; see also Articles 63(2) and 64(1) for straddling stocks and highly migratory species.
} 
the relevant RFMOs. ${ }^{71}$ If no such organisation exists with regard to straddling and highly migratory fish stocks, ${ }^{72}$ States with vessels fishing in the region "shall cooperate to establish such an organization or enter into other appropriate arrangements to ensure conservation and management of such stock and shall participate in the work of the organization or arrangement". ${ }^{73}$ Efforts to create an RFMO may fail for many reasons, but this does not free States from their obligation to genuinely attempt to establish such a cooperative mechanism.

The SMEFF Regulation remains silent on the need to cooperate in the management of unregulated high seas stocks. The CFP Basic Regulation refers to the obligation of the EU, for "stocks of common interest ... also exploited by third countries ..., [to] engage with those third countries with a view to ensuring that those stocks are managed in a sustainable manner ... Where no formal agreement is reached, the Union shall make every effort to reach common arrangements for fishing of such stocks with a view to making the sustainable management possible". ${ }^{74}$ According to another EU Regulation, a stock of common interest is

a fish stock the geographical distribution of which makes it available to both the Union and third countries and the management of which requires the cooperation between such countries and the Union, in either bilateral or multilateral settings. ${ }^{75}$

This somewhat all-encompassing definition referred, at least in the particular case of the dispute with the Faeroe Islands, to a fish stock which migrates

71 UnfSA (n 14), Article 8.

72 Strictly speaking, discrete high seas fish stocks are only covered by the Losc, with States called on to cooperate for their conservation ( $\operatorname{LOSC}(\mathrm{n} 12)$, Article 118), but with no mechanism provided therefor. Some authors argue that the obligation to cooperate in the LOSC nevertheless must lead to the creation of RFMos (see for example D Vignes, G Cataldi, and R Casado Raigón, Le droit international de la pêche maritime (Bruylant, Brussels, 2000), at p. 176). Moreover, the 2006 UNFSA Review Conference "encouraged States, as appropriate, to recognize that the general principles of the Agreement should also apply to discrete fish stocks in the high seas" (Report of the 2006 UNFSA Review Conference (A/CONF.210/2006/15, 5 July 2006), Outcome, para. 2).

73 UNFSA (n 14), Article 8(5).

74 CFP Basic Regulation (n 6), Article 33(1).

75 Regulation (EU) No 1026/2012 of the European Parliament and of the Council of 25 October 2012 on certain measures for the purpose of the conservation of fish stocks in relation to countries allowing non-sustainable fishing (Regulation on non-sustainable fishing), OJ L 316, 14 November 2012, 34-37, Article 2(a). 
between EEZs and areas of the high seas. ${ }^{76}$ The CFP Basic Regulation is thus arguably sufficient for the EU to respect its international obligation to cooperate regarding high seas unregulated stocks. However, it is worth comparing the soft call for cooperation in relation to stocks of common interest to the one for shared stocks, which are stocks moving between two or more EEZs. ${ }^{77}$ For shared stocks, the EU must "endeavour to establish bilateral or multilateral agreements with third countries for the joint management of stocks",78 an obligation of conduct explicitly aimed at reaching a formal agreement. The CFP provision on stocks of common interest is also in stark contrast with the internationally recognised need to establish RFMOs where there are none. ${ }^{79}$ In light of those considerations, an explicit reference in the SMEFF Regulation to the requirement of cooperation would have been welcome.

Moreover, it is unclear whether the current text of the SMEFF Regulation respects the EU law requirement that the same sustainability principles be applied to the internal and external dimensions of the EU fleet, in particular the obligation to apply an ecosystem-based approach to fisheries management. ${ }^{80}$ The SMEFF Regulation demands that unregulated high seas fishing follow and respect a scientific evaluation. This is a positive condition to authorising such operations. However, the provision makes no mention of the ecosystembased approach. Such silence is not the result of an oversight, given that the Parliament's proposal expressly addressed the issue ${ }^{81}$ and that the relevant terminology was nevertheless excluded. It may be implied that such a requirement is applicable through the CFP Basic Regulation, but an explicit mention

76 The Regulation on non-sustainable fishing served as a basis for the sanctions against the Faeroe Islands, a case involving the Atlanto-Scandian herring stock (Commission Implementing Regulation (EU) No 793/2013 of 20 August 2013 establishing measures in respect of the Faeroe Islands to ensure the conservation of the Atlanto-Scandian herring stock, OJ L 223, 21 August 2013, 1-7; see also J Weissenberger, 'North-East Atlantic fish stock disputes - The mackerel and herring conflicts' (Briefing European Parliamentary Research Service, 9 December 2013) available at http://www.europarl.europa.eu/ eplibrary/North-East-Atlantic-fish-stock-disputes.pdf; accessed 21 August 2018, at p. 3). This dispute was referred to Annex VII arbitration pursuant to the LOSC, but settled in 2014 (The Atlanto-Scandian Herring Arbitration (The Kingdom of Denmark in respect of the Faroe Islands v. The European Union), Termination Order, 23 September 2014, available at www.pcacases.com/web/view/25; accessed 21 August 2018); note that the description of the case refers to the application of Article 63(1), hence to shared stocks.

78 CFP Basic Regulation (n 6), Article 33(2).

79 UNGA, 'Sustainable Fisheries Resolution of 5 December 2017' (n 15), para. 143.

8o CFP Basic Regulation (n 6), Article 2(3).

81 Position of the European Parliament (n 66), Article 26(b). 
would have been preferable, in particular in light of the EU's ambiguous position vis-à-vis unregulated fishing.

The EU has made the fight against IUU fishing a policy priority, as reflected by the adoption of an instrument exclusively focused on this matter, the EU IUU Regulation. IUU fishing is also mentioned several times in the SMEFF Regulation with a view to ensuring that no authorisation is granted to a vessel identified as having committed IUU fishing ${ }^{82}$ or having been involved with a country identified as non-cooperating in the fight against IUU fishing. ${ }^{83} \mathrm{In}$ none of these places does the EU differentiate between, on the one hand, illegal and unreported fishing and, on the other hand, potentially permissible unregulated fishing. However, when it comes to authorising its own vessels to fish in an unregulated manner, the EU provides a framework that, although an improvement on what it replaces, is not as ambitious or comprehensive as it could have been with regard to cooperation and the ecosystem-based approach to fisheries management.

\section{Fishing within the Frameworks of SFPAs and RFMOS}

In the SMEFF Regulation, the two other types of fishing operations outside of EU waters (i.e., within the framework of an SFPA or RFMO) do not explicitly require the respect of sustainability criteria. Such a condition is implied in the provisions of the CFP Basic Regulation, but without a reference to the fishing authorisation stage itself. The CFP Basic Regulation also lacks the level of detail and procedural steps developed in the SMEFF Regulation.

With regard to fishing under SFPAs, hard international law requires the coastal State to ensure that stocks are not overexploited, as was noted in relation to fishing under direct authorisations. The Voluntary Guidelines for Flag State Performance exhort coastal and flag States to "only enter into fisheries access agreements ... when both are satisfied that such activities will not undermine the sustainability of living marine resources within the jurisdiction of the coastal State". ${ }^{84}$

As a matter of EU law, the CFP Basic Regulation states that, under SFPAs, in addition to the general sustainability principles and objectives of Articles 2 and 3 ,

Union fishing vessels shall only catch surplus of the allowable catch as referred to in Article 62(2) and (3) of the UNCLOS [LOSC], and identified,

$82 \quad$ SMEFF Regulation (n 1), Articles (1)(d), 6(2)(a).

83 Ibid., Article 6(2)(c)-(d), (4)(a)-(b).

84 Voluntary Guidelines for Flag State Performance (n 20), para. 40. 
in a clear and transparent manner, on the basis of the best available scientific advice and of the relevant information exchanged between the Union and the third country about the total fishing effort on the affected stocks by all fleets. Concerning straddling or highly migratory fish stocks, the determination of the resources available for access should take due account of scientific assessments conducted at the regional level as well as conservation and management measures adopted by relevant RFM Os. ${ }^{85}$

This generic obligation, which unfortunately has not always been respected, ${ }^{86}$ does not clarify what information is provided to the Commission or establish a procedure to review determinations by the coastal State. Whereas the operator wishing to fish under a direct authorisation must actually demonstrate sustainability on the basis of a scientific evaluation, fishing under an SFPA can be allowed on the basis of the best available scientific advice and taking due account of regional scientific assessments. Not only is the procedure for fishing under SFPAS less transparent and potentially less robust than for fishing under direct authorisations, but the threshold also appears to be lower.

The SMEFF Regulation cannot amend the CFP Basic Regulation. However, it could have included a procedure to be followed and a clear obligation that the Commission must actively demonstrate sustainability before authorising fishing under SFPAs. The EU may not be under a strict international law obligation to prove or even verify the sustainability of fishing within another State's EEZ, but this is becoming the best practice expected of flag States, and the internal coherence of the SMEFF Regulation would have been increased.

Somewhat similar remarks can be made regarding fishing within the framework of RFMOS. According to the CFP Basic Regulation,

The positions of the Union in international organisations dealing with fisheries and in RFMOs shall be based on the best available scientific advice so as to ensure that fishery resources are managed in accordance with the objectives laid down in Article 2, in particular paragraph 2 and point (c) of paragraph 5 thereof ... ${ }^{87}$

85 CFP Basic Regulation (n 6), Article 31(4).

86 See for example the circumstances of the signature of the SFPA Protocol with GuineaBissau in 2014 (COFREPECHE, MRAG, NFDS, and Poseidon, 'Évaluation rétrospective et prospective du protocole de l'accord de partenariat dans le secteur de la pêche entre l'Union européenne et la République de Guinée-Bissau' (Brussels, Contrat cadre MARE/2011/o1 - Lot 3, contrat spécifique no 17, 2016), at pp. 124-125).

87 CFP Basic Regulation (n 6), Article 29(2). 
This obligation of conduct binding the EU for its actions within RFMOs stands in stark contrast to the obligation of result to provide an evaluation demonstrating the sustainability of planned fishing operations for unregulated high seas fishing. Whereas the EU may generally push for sustainable measures within RFMOs, no such result can be guaranteed in a multilateral forum. In practice, as demonstrated at least partly by the status of many stocks, decisions within RFM Os have not always been based on the best available science. ${ }^{88}$ Although it is an unlikely scenario in practice, one could argue that, in order to be consistent with the CFP Basic Regulation, fishing authorisations for vessels of EU Member States should only be granted after the specific operations' sustainability has actually been demonstrated. This would mean that the EU should, in certain cases, not authorise fishing for the totality of the quotas allocated to it within RFMOS.

\section{An Element of Control and Transparency}

The SMEFF Regulation creates an element of control, by the Commission, over the issuance of fishing authorisations by EU Member States. As examined below, there are procedures both to hinder such issuance if the requisite criteria are not met and to respond to violations of the conditions of an authorisation after the fishing has started. Compared to the Fishing Authorisation Regulation, which included a provision on the non-transmission of applications to coastal States and RFMOs, the novel aspect of such control is mainly the inclusion of a control mechanism after an authorisation has been granted. In addition to direct control by the Commission, transparency is given a prominent place in the SMEFF Regulation through a new database of fishing authorisations, some parts of which are available to the public.

\section{Control by the Commission}

Under international law, flag States are under an obligation to control their vessels, wherever they may be active. As mentioned in the introduction, although the Member States are the flag States, the international responsibility of the EU itself may be invoked in certain cases. The EU has exclusive

88 S Cullis-Suzuki and D Pauly, 'Failing the high seas: A global evaluation of regional fisheries management organizations' (2010) 34(5) Marine Policy 1036-1042; KM Gjerde, D Currie, K Wowk, and K Sack, 'Ocean in peril: Reforming the management of global ocean living resources in areas beyond national jurisdiction' (2013) 74 Marine Pollution Bulletin 540551, at pp. 543-544. 
competence with regard to the conservation of marine biological resources under the $\mathrm{CFP} ;{ }^{89}$ it alone can enter into SFPAs and, subject to some exceptions, act within RFMOs. ${ }^{90}$ In 2016, the International Tribunal for the Law of the Sea (ITLOS) rendered an advisory opinion on IUU fishing in West Africa, in which it stated that

in cases where an international organization, in the exercise of its exclusive competence in fisheries matters, concludes a fisheries access agreement with an SRFC [Sub-Regional Fisheries Commission] Member State, which provides for access by vessels flying the flag of its member States to fish in the exclusive economic zone of that State, the obligations of the flag State become the obligations of the international organization. The international organization, as the only contracting party to the fisheries access agreement with the SRFC Member State, must therefore ensure that vessels flying the flag of a member State comply with the fisheries laws and regulations of the SRFC Member State and do not conduct IUU fishing activities within the exclusive economic zone of that State. ${ }^{91}$

This passage, as most of the advisory opinion, focused on fishing within the EEZs of third States, but the same reasoning can logically apply to fishing activities within an RFMO. As an obligation of conduct, "[t]he flag State [or, mutatis mutandis, the international organization] is under the 'due diligence obligation' to take all necessary measures to ensure compliance and to prevent IUU fishing by fishing vessels flying its flag". ${ }^{92}$ Consequently, for the types of fishing in relation to which it has exclusive competence, the $\mathrm{EU}$ must have the means to control vessels flying the flags of Member States. The Commission, as the executive branch of the EU, is the entity empowered to exercise such control.

\section{Before Issuance of the Authorisation (ex ante Control)}

Under the SMEFF Regulation, flag States remain in control of issuing fishing authorisations. However, the Commission has the potential to exercise some level of control over that process. Each type of fishing activity triggers a different kind of ex ante control, in contrast to the Fishing Authorisation Regulation, which included a general article applicable to the types of fishing that were substantially covered (see supra, section on External Fishing Wherever It Takes Place). Under the Fishing Authorisation Regulation, the Commission was not

\footnotetext{
$89 \quad \operatorname{TFEU}(\mathrm{n}$ 1), Article $3(\mathrm{~d})$.

9o CFP Basic Regulation (n 6), Articles 29-32. On the exceptions, see $\mathrm{n} 18$.

91 ITLOS, Request for an Advisory Opinion Submitted by the SRFC (n 19), para. 172.

92 Ibid., para. 129.
} 
to transmit applications to the authorising authorities (i.e., RFM Os and coastal States with which an SFPA was in place) if the applications were incomplete, the fishing opportunities were insufficient, or other conditions were not complied with. ${ }^{93}$

In the SMEFF Regulation, for fishing under an SFPA, the authorisation by the flag State must be combined with an authorisation from the coastal State. Contacts with the coastal State are handled by the Commission. Accordingly, the Commission can exert some control within this window when it requests the authorisation by the coastal State. After the Commission receives the application from the flag State, it undertakes a preliminary examination to determine whether the conditions listed in Article 10 are fulfilled. On the basis of this examination, the Commission has the choice to send the application to the coastal State or to inform the flag State that the application was refused. ${ }^{94}$ In that latter case, the flag State cannot issue a fishing authorisation, as it will not be in possession of the required authorisation from the coastal State. ${ }^{95}$

In the case of fishing within the framework of an RFMO, the Commission has a similar role of intermediary to play. However, the relevant provision of the SMEFF Regulation is formulated in slightly ambiguous terms: "[w]hen it is satisfied that the conditions set out in Article 21 are met ... the Commission shall send the details of the authorised vessels to the RFMO".96 Unlike in the case of fishing under an SFPA, nothing is said about the consequences of the Commission finding that the conditions are not met. Nevertheless, in such circumstances, the Commission, by not contacting the RFMO with the details of the vessels, prevents their inclusion in the list of authorised vessels of the RFMO, which is an explicit requirement under the SMEFF Regulation for fishing within the framework of an RFMO. ${ }^{97}$

Fishing under direct authorisations requires an authorisation from the coastal State, but the operator is responsible for obtaining it. ${ }^{98}$ According to Article 18 of the SMEFF Regulation, entitled "Procedure for obtaining fishing authorisations of the third country", if the Commission considers that the conditions listed in Article 17 are not met, "it may object to the granting of the fishing authorisation". ${ }^{99}$ Article 18 is ambiguous in that, beyond its title, it is unclear whether it actually concerns the coastal State's authorisation. Paragraph 3 does

93 Fishing Authorisation Regulation (n 2), Article 7. For the absence of control over the other two types of fishing, see Article 11.

94 SmefF Regulation (n 1), Article 11(4).

95 Ibid., Article 10(d).

$96 \quad$ Ibid., Article 22(4).

97 Ibid., Article 20(1)(c).

$98 \quad$ Ibid., Article $17(1)(\mathrm{e})$.

99 Ibid., Article 18(3). 
not state to which of the coastal State's or flag State's authorisation it refers, but paragraph 4, which addresses the situation in which the Commission does not object, clarifies that the Member State can then issue the fishing authorisation. It would in any case appear that the Commission has no power to object to a coastal State granting an authorisation. Beyond this apparent disconnect between title and content, Article 18 implies that, should the Commission object, the flag State cannot issue the necessary fishing authorisation under EU law. Similarly, for unregulated high seas fishing, the procedure to obtain a fishing authorisation also envisages that the Commission may object if the required conditions are not met.100

The ex ante role of the Commission is somewhat ambiguous and appears to vary for each type of fishing activity. In particular, the difference in wording between the procedures for fishing within the frameworks of SFPAS and RFMOS is surprising; it is difficult to understand why the Commission would only have implied powers to refuse to transmit the list of vessels to the RFMO, when the EU has exclusive competence within these regional organisations. The fragmentation and reliance on implied powers in the SMEFF Regulation are a step backwards in comparison to the provision of the Fishing Authorisation Regulation, which expressly provided for the non-transmission of an application for fishing within the frameworks of both SFPAs and RFMOs. ${ }^{101}$

In any case, the Commission is in the position to impair the legality, under international law, of fishing within the framework of SFPAS or RFMOs by not contacting the entities that must, respectively, issue a second authorisation or list the authorised vessels. It consequently seems that the EU's obligation of due diligence can be met with regard to the types of fishing activities where the EU is at risk of having its international responsibility invoked. The Commission is also empowered to object to the issuance of fishing authorisations by the flag State for fishing under direct authorisations and for unregulated high seas fishing; were the flag State nevertheless to issue an authorisation, it would be in violation of EU law. The inclusion of such objecting powers, albeit not required under international law, is a welcome additional layer of supervision. It is also an improvement when compared to the total absence of control by the Commission, under the Fishing Authorisation Regulation, over these two types of fishing.

\section{After Issuance of the Authorisation (ex post Control)}

In addition to the ex ante control described above, the Commission can, in certain cases, exert ex post control in relation to violations of the applicable

\footnotetext{
$100 \quad$ Ibid., Article 25(3).

101 Fishing Authorisation Regulation (n 2), Article 7.
} 
conditions to fish. Article 7 (6)-(7) addresses the situation of a fishing vessel from a Member State not having complied with the conditions to fish set out, respectively, in the RFMO rules or the SFPA, and of the flag State not having taken appropriate action. Appropriate action would consist in the amendment or withdrawal of the authorisations or in the imposition of sanctions of sufficient severity so as to prevent infringements and deprive offenders of the benefits derived from infringements. In the absence of such action, the Commission is entitled to step in. First, the Commission may require the flag State to act as it ought to. Second, if this instruction is not followed through within 15 days, the Commission must send the details of the relevant vessel to the RFMO or coastal State concerned, in order "to address the vessel concerned".

This discretionary power of the Commission to instruct the flag State to remedy its failure ("may"), followed by a compulsory notification of the RFMO or coastal State authorities ("shall"), is novel in comparison to the Fishing Authorisation Regulation, which did not envisage any such procedure. It does not create a 'super-flag State', because each flag State remains in charge of its own vessels, with the Commission intervening solely in certain cases of obvious mismanagement. The Commission's powers also do not extend to a comprehensive review of the actions of EU flag States; only fishing within the framework of an SFPA or RFMO can trigger such control. The SMEFF Regulation remains silent with regard to any ex post control over EU flag States for the other types of distant-water fishing.

In addition to the lack of ex post control over certain types of fishing, the main weakness of this provision is what its ambiguous phrasing implies. Article 7 (6)-(7) does not state that the Commission can withdraw fishing authorisations or order Member States to do so. ${ }^{102}$ Instead, the Commission "shall send the updated details of the fishing vessels". In other words, the Commission must turn to the RFMO or coastal State and request that they withdraw the fishing authorisation or remove the vessel from the list of authorised vessels; the Commission hands over the actual decision to act to another entity.

EU legislators were aware of the EU's international obligations as clarified by ITLOS ${ }^{103}$ and this consideration certainly influenced the inclusion of the Article 7 claw-back provisions. It is, however, unclear whether the limited powers provided to the Commission under the SMEfF Regulation suffice to

102 The Commission's proposal had envisaged such power for all types of fishing, but it was rejected (Commission's proposal (n 47), Article 7(6): "If a flag Member State fails to refuse, amend, suspend or withdraw the authorisation in accordance with paragraphs 4 and 5 , the Commission may decide to withdraw the authorisation and notify the flag Member State and the operator accordingly").

103 Commission's proposal (n 47), Explanatory Memorandum, at p. 3; Position of the European Parliament (n 66), Preamble 3a, 5 . 
ensure that the EU can take all necessary measures against Member States' vessels violating the applicable fishing conditions in the EEZ of a third country with which an SFPA exists or in an RFMO. The lack of clear power to withdraw authorisations could lead to the conclusion that the EU remains liable under international law, should one of its Member States' vessels violate applicable regulations and should the Member State fail to react appropriately.

\section{Transparency}

Another novel aspect of the framework created by the SMEFF Regulation relates to transparency. Article 39 of the SMEFF Regulation provides for the creation of a database of fishing authorisations, part of which is to be made public. Nothing similar was envisaged in the Fishing Authorisation Regulation.

\section{Database Content}

The database will consist of the information contained in the Annex of the SMEFF Regulation, including the name and flag of the vessel, its Community Fleet Register and Imo numbers if required under EU law, the type of authorisation, the target species, and the authorised times and areas of the fishing operation. It will also contain information related to the identity of the owner and of up to five main beneficial owners. ${ }^{104}$

Under international law, a flag State is required to maintain a database of vessels flying its flag, ${ }^{105}$ but nothing is said about a database of fishing authorisations. In terms of EU law, the fishing fleet register is provided for in the CFP Basic Regulation. Accordingly, Member States and the Commission must maintain records on, respectively, their own and all EU fishing vessels. ${ }^{106}$

The creation of a central database of fishing authorisations is a noteworthy and positive innovation of the SMEFF Regulation. Although not required by international law, it will be beneficial to effective control, by allowing the EU to have an overview of the identity of all vessels flying Member States' flags that are active outside of EU waters. The EU was already supposed to be aware and informed of the vessels making up its external fleet. However, this was most probably not the case for vessels fishing under direct authorisations, as Member States were only under the obligation to "endeavour to obtain information" on such arrangements and inform the Commission thereof. The Commission will also benefit from more comprehensive information on the type of authorisation, target species, authorised times, and areas of fishing

\footnotetext{
104 SMEFF Regulation (n 1), Article 39(1)-(2) and Annex.

$105 \operatorname{LosC}(\mathrm{n}$ 12), Article 94(1)(a); Compliance Agreement (n 13), Article IV; UnfSA (n 14), Article 18(3)(c).

106 CFP Basic Regulation (n 6), Article 24.
} 
of all fishing operations. For fishing under direct authorisations in particular, this is a major improvement in comparison to the Fishing Authorisation Regulation, which only called on Member States to inform the Commission of the names of the vessels involved. ${ }^{107}$

\section{Data on Beneficial Ownership}

The inclusion of information on beneficial ownership has a role to play in promoting sustainable fisheries. Indeed, such details can serve to deter IUU and unsustainable fishing practices by making it possible to financially sanction the actual beneficiary. Although it is the State of nationality that will generally be in the best position to impose sanctions on the beneficial owners, ${ }^{108}$ information must be gathered before it can be shared with other States.

There is no rule of international law, at the global level, requiring States to gather data on beneficial ownership. However, some soft-law instruments recognise this as best practice. In particular, the IPOA-IUU calls for States to include details on beneficial ownership in their records of fishing vessels ${ }^{109}$ and to "cooperate to identify those nationals who are the operators or beneficial owners of vessels involved in IU U fishing". ${ }^{110}$ Similarly, the Voluntary Guidelines for Flag State Performance state that flag States should "follow ... minimum requirements, such as ... (b) information on vessel owners and operators which identifies effective beneficial owners and operators" 111 and provide that the record of fishing vessels kept by each flag State may include data on the natural or legal persons with beneficial ownership of the vessel. ${ }^{112}$ Under EU law, although ownership is mentioned in the CFP Basic Regulation,, ${ }^{113}$ beneficial ownership is absent from both that instrument and the Control Regulation. It has, however, been introduced in the Anti-Money Laundering Directive, ${ }^{114}$ which will be examined below.

\footnotetext{
107 Fishing Authorisation Regulation (n 2), Article 11(2).

108 UNGA, 'Sustainable Fisheries Resolution of 5 December 2017' (n 15), para. 74; IPOA-IUU (n 20), para. 18.

109 IPOA-IUU (n 20), para. 42(4).

110 Ibid., para. 18.

111 Voluntary Guidelines for Flag State Performance (n 20), para. 14(b).

112 Ibid., para. 25(d).

113 CFP Basic Regulation (n 6), Article 24(1).

114 Directive (EU) 2015/849 of the European Parliament and of the Council of 20 May 2015 on the prevention of the use of the financial system for the purposes of money laundering or terrorist financing (Anti-Money Laundering Directive), OJ L 141, 5 June 2015, 73-117, as amended by Directive (EU) 2018/843 of the European Parliament and of the Council of 30 May 2018 amending Directive (EU) 2015/849 on the prevention of the use of the financial system for the purposes of money laundering or terrorist financing (2018 Amendment to Anti-Money Laundering Directive), OJ L 156, 19June 2018, 43-74.
} 
The Commission's original proposal for the SMefF Regulation was silent on the question of beneficial ownership, and the current provision is the result of a compromise between the Parliament and the Council, on the basis of the Parliament's proposal. ${ }^{115}$ The SM EFF Regulation refers to beneficial ownership exclusively as something that must be in the database. Article 39 (1) (a) states that the database "shall record ... other information submitted to the Commission for the purpose of issuing fishing authorisations under Titles II and III, including the name, city, country of residence ... of up to five main beneficial owners". Information about beneficial ownership, however, is not listed in the Annex as data that must be provided. The database provision anticipates that such information will be made available to the Commission, but without a clear obligation for Member States to do so.

The Commission is empowered to amend the Annex "to ensure appropriate monitoring of the activities of fishing vessels under this Regulation".116 This could be a way to explicitly require States to provide the names of beneficial owners. This would increase the internal coherence of the SMEFF Regulation on an issue important for achieving sustainable and responsible fisheries and ensure that, in the absence of information on beneficial ownership, no fishing authorisation would be granted. The EU is not under any international law obligation to gather this information or require it as a condition to issue fishing authorisations, but it could easily improve its 'good practice' to 'best practice'.

\section{Public Access to Information}

As noted above, some of the information in the database of fishing authorisations will be made publicly available. The general public will be able to access information on the name and flag of a vessel, its Community Fleet Register and IMO numbers, the type of authorisation, the target species, and the authorised times and areas of the fishing operation. ${ }^{117}$ The secure part of the database, which is only accessible to the relevant administrative services involved in the management of fishing fleets, ${ }^{118}$ includes all the remaining information to

115 See Commission's proposal (n 47), Article 39; Position of the European Parliament (n 66), Article 39; European Commission, 'Communication from the Commission to the European Parliament pursuant to Article 294(6) of the TFEU concerning the position of the Council on the adoption of a Regulation of the European Parliament and of the Council on the sustainable management of external fishing fleets, repealing Council Regulation (EC) No 1006/2008' (Communication from the Commission to the Parliament) (COM/2017/0633 final, 2015/0289 (COD), 25 October 2017), at p. 4.

116 SMEFF Regulation (n 1), Article 5(2).

117 Ibid., Article 39(2).

118 Ibid., Article 41. 
be provided according to the Annex, as well as the information related to the identity of the owner and the main beneficial owners. ${ }^{119}$

Under international law, no obligation exists for States to make any data about fishing authorisations publicly available. However, with regard to the fishing fleet register, the Voluntary Guidelines for Flag State Performance provide that flag States should "make ... registry data publicly available and easily accessible subject to any applicable confidentiality requirements". ${ }^{120}$ Under EU law, similarly, public access is to be provided to the data in the fishing fleet register, whereas personal data are to be protected. ${ }^{121}$ Transparency is also mentioned in the CFP Basic Regulation as one of the principles of good governance, subject to existing legal requirements, due respect for private life, the protection of personal data, and confidentiality rules. ${ }^{122}$

The existence of a public part to the fishing authorisations database is a major step towards making information available on which fishing vessels are active in which areas and on the conditions under which they are fishing. Together with the FAO Global Record, this may support civil society's important work in identifying vessels that are not respecting the rules ${ }^{123}$ and help governments address illegal fishing activities. ${ }^{124}$ It will also be particularly useful for the public to finally know the size of the EU external fleet. Indeed, a request for information by a group of non-governmental organizations (NGOS) in 2014 showed a very large discrepancy between the announced number of vessels fishing externally $\left(718\right.$ in 2007) ${ }^{125}$ and the individual vessels that were authorised to fish externally (averaging 3816 per year). ${ }^{126}$

The compromise found by the European Council and the European Parliament during the trilogue removed the information about beneficial ownership

119 Ibid., Article 39(1)(a).

120 Voluntary Guidelines for Flag State Performance (n 20), para. 22.

121 CFP Basic Regulation (n 6), Article 24(3).

122 Ibid., Article $3(\mathrm{k})$.

123 See for example the initiative 'VISIBLE' by Stop Illegal Fishing, an African-based not for profit organisation fighting IUU fishing, available at https://stopillegalfishing.com/initiatives/visible/; accessed 21 August 2018.

124 G Lugten, 'Current Legal Developments - Food and Agriculture Organization' (2008) 23 The International Journal of Marine and Coastal Law 761-767, at p. 764 .

125 The number of 718 does not represent all vessels active outside of the EU waters, because the study which reached this result looked only at vessels that operated more than $90 \%$ of the time outside of EU waters ('Study on the European External Fleet' (Final Report, Contract FISH/2006/02, January 2008), at p. 3). There are other numbers available regarding the external fishing fleet, such as that of 285 vessels in 2015 (Scientific, Technical and Economic Committee for Fisheries (STECF), 'The 2017 Annual Economic Report on the EU Fishing Fleet' (Luxembourg, Publications Office of the European Union, STECF-17-12, 2017), at p. 67).

126 Who Fishes Far, 'Transparency, Accountability and Sustainability' (n 32). 
from the public part of the database. The European Parliament - supported by a number of $\mathrm{NGOS}^{127}$ - had pushed for the inclusion of such data not only in the database, but also in the public part thereof. This was, however, considered unacceptable by the European Council, because of concerns related to data protection and to the protection of commercial interests. ${ }^{128}$ Consequently, the SMEFF Regulation does not provide for the possibility for anyone other than the relevant administrative services to access information on beneficial ownership. ${ }^{29}$

The clear-cut division in the SMEFF Regulation between publicly accessible information and confidential data is different from the rules in the Anti-Money Laundering Directive, which can be used to obtain beneficial ownership information. Under that 2015 instrument, Member States are obliged to hold, each in a central register, information about the "corporate and other legal entities incorporated within their territory", including information on beneficial ownership. ${ }^{130}$ According to a 2018 amendment to the Anti-Money Laundering Directive - the new provisions of which are to be transposed by Member States into their national laws by 2020 -, Member States are required to make this information accessible to "any member of the general public". 131 This is a wider access than was envisaged in the 2015 instrument, where it was restricted to "any person or organization that can demonstrate a legitimate interest".132 Even then and although there was a margin of discretion in how a legitimate interest would be assessed by the various national authorities, this provision nevertheless already offered a possible avenue to obtain information. ${ }^{133}$ In light both of the impact of the external fleet on the long-term sustainability of common resources and of the subsidised nature of EU vessels' fishing operations under SFPAs, ${ }^{134}$ environmental organisations and EU citizens could

127 See for example the 'Call on the European Parliament to support transparency of the EU external fishing fleet' (23 January 2017) available at http://www.bloomassociation.org/ wp-content/uploads/2017/01/20170123_OGP_Letter-MEPs-Beneficial-Ownership-Final. pdf; accessed 21 August 2018.

128 Communication from the Commission to the Parliament ( $\mathrm{n} 115$ ), at pp. 4-5.

129 SMEFF Regulation (n 1), Article 41.

130 Anti-Money Laundering Directive (n 114), Article 30(1), (3).

1312018 Amendment to Anti-Money Laundering Directive (n 114), para. 15(c).

132 Anti-Money Laundering Direction (n 114), Article 3o(5)(c).

133 A Standing, 'Transparency in Beneficial Ownership of Fishing Companies: The Opportunity For the EU's Fishing Authorisation Regulation' (CFFA-CAPE, 25 November 2016) available at https://cape-cffa.squarespace.com/newblog/2016/11/25/transparencyin-beneficial-ownership; accessed 21 August 2018.

134 The payments to coastal States under SFPAs are made by the EU. It means that the operators do not have to bear the full costs of fishing and these payments could consequently be considered subsidies (I Popescu, 'Beyond the European seas - The external dimension 
possibly demonstrate a legitimate interest vis-à-vis the owners of fishing vessels registered in the EU.

It is unclear, however, whether access to information on the beneficial ownership of fishing vessels through the Anti-Money Laundering Directive can effectively replace the lack of similar access through the SMEFF Regulation. To be considered a EU fishing vessel, a vessel must fly the flag of a Member State and be registered in the EU. ${ }^{135}$ Except for this reference to the vessel being registered in the EU, there seems to be no EU requirement that the owner of the vessel be based in a Member State and hence subject to the Anti-Money Laundering Directive. ${ }^{136}$ In addition to an issue of unequal treatment between $\mathrm{EU}$ and non-EU owners of EU vessels, the different levels of public access to information on beneficial ownership under the SMEFF Regulation and the Anti-Money Laundering Directive raise a question of consistency between two pieces of EU legislation, another good governance principle explicitly recalled in the CFP Basic Regulation. ${ }^{137}$

\section{Conclusion}

In terms of scope of application, the SMEFF Regulation fills in the gaps that existed in the Fishing Authorisation Regulation with regard to fishing under direct authorisations and unregulated high seas fishing. This ensures that, in addition to the EU being fully compliant with the obligation to control its vessels wherever they are active, all types of external fishing are coherently covered. The SMEFF Regulation also widens the scope of activities requiring a fishing authorisation by regulating some aspects of chartering, which goes beyond the EU's international law obligations.

In terms of criteria, the SMEFF Regulation establishes general conditions that must be fulfilled before an authorisation to fish can be issued, applicable in all cases of external fishing. The inclusion of the IMO number requirement is not new under EU law and the scope of application of the obligation is not

of the Common Fisheries Policy' (In-Depth Analysis of the European Parliamentary Research Analysis, November 2015), at p. 18).

135 CFP Basic Regulation (n 6), Article 4(1)(5).

136 The conditions for registration of vessels are determined by each Member State in its role as flag State. It seems that these conditions do not necessarily require that vessels are owned by corporations established in the flag State or in another EU Member State (see for example Deputy Ministry of Shipping of the Republic of Cyprus, 'Ownership Conditions' available at http://www.dms.gov.cy/dms/dms.nsf/registerships_en/register ships_en?OpenDocument; accessed 21 August 2018). CFP Basic Regulation (n 6), Article 3(h). 
widened under the SMEFF Regulation, but it is nevertheless a positive reaffirmation that the use of this unique vessel identifier is becoming the norm. Conditioning the issuance of a fishing authorisation to a vessel having reflagged in the last five years on proof that it was not abusing the system is equally a good practice and will support compliance with international obligations binding the EU. The specific criteria for different types of fishing operations require, for fishing activities under direct authorisations or for unregulated high seas fishing, that the operator prove the sustainability of the planned operations. This condition and the related procedures strongly contribute to ensuring respect for the obligation, under EU law, that fishing practices be sustainable both within and outside EU waters; this goes beyond what is at present required by international law with respect to fishing in the EEzs of third States, but is in line with recent soft-law instruments. The sustainability criteria, however, are not applicable to all types of fishing, which is regrettable in terms of substance and coherence. Moreover, the conditions for allowing unregulated high seas fishing could have been clearer; in the absence of any explicit obligation to cooperate with a view to establishing an RFMO or to apply an ecosystem-based approach to fisheries management, the new Regulation may still be at odds with international and European obligations.

In terms of control and transparency, the SMEFF Regulation provides for some controls, by the Commission, before authorisations can be issued by the flag State. This ensures that the EU can respect its international obligation to exercise control over vessels on an ex ante basis. However, the lack of consistency in the terms used and procedures to be followed is regrettable, especially for fishing within the framework of RFMOs, where the EU's international responsibility is at play. Whereas the widened scope of the controls under the SMEFF Regulation is an improvement over the Fishing Authorisation Regulation, it is unfortunate that the Commission's explicit power to refrain from transmitting an application to an RFMO was lost. The SMEFF Regulation also provides for some ex post control by the Commission, as it can request a Member State to take remedial action towards its vessels and is entitled to intervene if that proves unsuccessful. Although this double-level control is welcome, it is only applicable to fishing under SFPAs and RFMOs, the frameworks where the EU could be held liable. Even then, it is unclear whether the Commission's powers are enough to satisfy the EU's obligation of due diligence. Finally, the SMEFF Regulation mandates the establishment of a database of fishing authorisations, some aspects of which will be made available to the general public. As the EU is under no such obligation in international law, this initiative is commendable and will improve control and transparency. The inclusion of information on beneficial ownership in the database is a positive addition to the 
original proposal by the Commission, although the ambiguity as to the actual existence of an obligation for Member States to provide such data and the absence of public access to that information can be regretted.

In conclusion, the SMEFF Regulation strengthens many aspects of the framework under which authorisations are granted to EU vessels seeking to fish outside of EU waters, in particular when compared to the Fishing Authorisation Regulation. It applies to all types of external fishing, conditions the granting of authorisations on sustainability criteria, establishes a level of institutional control over Member States' actions, and at the same time provides some transparency as to who fishes where. Furthermore, the SMEFF Regulation includes practices that have been poorly monitored so far, such as reflagging and chartering. However, some aspects remain sub-par vis-à-vis international and European law, or are simply not the best practices which could have been expected from the EU. In particular, the provision on unregulated high seas fishing is problematic on both legal and policy levels. The lack of coherence regarding sustainability criteria and controls is also to be deplored, because it leaves some fishing activities better regulated and controlled than others. Finally, the total lack of public access to data on beneficial ownership is difficult to reconcile with the EU's commitment to good governance principles.

What remains unclear is whether this new and stricter Regulation will make a substantial contribution to improving the sustainability of fishing activities around the world. Indeed, the EU is only one player in the distant-water fishing sector, with other major States/entities involved, mainly China, Japan, South Korea, Russia, and Taiwan. The size of China's distant-water fishing fleet in particular has increased dramatically in the last decade; it may likely now be the largest in the world. ${ }^{138}$ It is consequently problematic that no official and reliable data are available on the level of Chinese catches. ${ }^{139}$ Serious concerns regarding unsustainable practices and IUU fishing have also been voiced..$^{140}$ Moreover, beyond these country-specific issues, transparency and the robust assessment of sustainability are not goals equally pursued by all the major

${ }_{13} 8$ R Blomeyer, I Goulding, D Pauly, A Sanz, and K Stobberup, 'The Role of China in World Fisheries' (Brussels, Study requested by the European Parliament's Committee on Fisheries, IP/B/PECH/IC/2011-107, June 2012), at p. 37.

139 On reporting issues and estimations of the Chinese distant-water fishing vessels' catches, see D Pauly, D Belhabib, R Blomeyer, WWWL Cheung, AM Cisneros-Montemayor, D Copeland, S Harper, VWY Lam, Y Mai, F Le Manach, H Österblom, KM Mok, L van der Meer, A Sanz, S Shon, UR Sumaila, W Swartz, R Watson, Y Zhai, and D Zeller, 'China's distant-water fisheries in the 21st century' (2014) 15 Fish and Fisheries 474-488.

140 TG Mallory, 'China's distant water fishing industry: Evolving policies and implications' (2013) 38 Marine Policy 99-108, at pp. 103-104. 
distant-water fishing actors. Several of these other States/entities keep their agreements with coastal States completely confidential and do not provide information on decision-making processes that lead to fishing authorisations.

Against this background, the EU's ambitious rules may prove beneficial in the mid- or long-term as examples to follow, or sooner for coastal States that prioritise good governance and the sustainable management of resources over short-term gains. However, in addition to the risks to the competitiveness of the EU fishing sector, the EU's measures may equally have no impact - or even a negative one - on the sustainability of stocks if coastal States prefer to enter into agreements with those flag States that impose fewer conditions or require lower levels of control. ${ }^{141}$ It is also problematic in any case that most other access agreements remain secret and hence cannot be taken into account to determine actual surpluses. More generally, in the strongly interconnected world of fisheries, measures related to sustainability have a limited impact if they remain unilateral. Only the future will tell whether the much-needed good governance principles that the EU attempts to promote, albeit imperfectly, will take hold and become the norm for all.

141 A Gagern and J van den Bergh, 'A critical review of fishing agreements with tropical developing countries' (2013) 38 Marine Policy $375^{-386}$, at p. 383 . 